\title{
ENVIRONMENTAL PERFORMANCE, INTELLECTUAL CAPITAL, PRAKTIK PENGHINDARAN PAJAK DAN NILAI PERUSAHAAN
}

\author{
EKA SEPTIANI \\ HOLIAWATI \\ ENDANG RUHIYAT \\ Universitas Pamulang, Jl. Surya Kencana No.1, Pamulang Bar., Kec. Pamulang, Kota Tangerang Selatan, \\ Banten 15417, Indonesia \\ holiawati_76@yahoo.co.id
}

\begin{abstract}
This study aims to examine the effect of environmental performance, intellectual capital and tax avoidance practices on firm values. This type of research is quantitative by using the population in this study is a manufacturing company that is listed on the Indonesia Stock Exchange in 2012-2016. The selection of data samples using a purposive sampling technique. The analytical method used is multiple linear regression analysis. The results of this study indicate that environmental performance has no effect on company values, intellectual capital has a positive and significant effect on corporate values and tax avoidance practices that have a negative and significant effect on firm value.
\end{abstract}

Keywords: Environmental performance, intellectual capital, tax avoidance practices, firm value

Abstrak: Penelitian ini bertujuan untuk menguji pengaruh kinerja lingkungan, modal intelektual dan praktik penghindaran pajak terhadap nilai-nilai perusahaan. Jenis penelitian ini adalah kuantitatif dengan menggunakan populasi dalam penelitian ini adalah perusahaan manufaktur yang terdaftar di Bursa Efek Indonesia pada tahun 2012-2016. Pemilihan sampel data menggunakan teknik purposive sampling. Metode analisis yang digunakan adalah analisis regresi linier berganda. Hasil penelitian ini menunjukkan bahwa kinerja lingkungan tidak berpengaruh terhadap nilai-nilai perusahaan, modal intelektual berpengaruh positif dan signifikan terhadap nilainilai perusahaan dan praktik penghindaran pajak yang memiliki pengaruh negatif dan signifikan terhadap nilai perusahaan.

Kata kunci: Kinerja lingkungan, modal itelektual, praktik penghindaran pajak, nilai perusahaan

\section{PENDAHULUAN}

Perkembangan di bidang ekonomi memiliki dampak yang cukup signifikan terhadap pengelolaan suatu bisnis dan penentuan strategi bersaing. Persaingan yang semakin ketat membuat setiap perusahaan meningkatkan kinerja agar dapat mencapai tujuannya. Karena jika kinerja perusahaan baik maka tingkat pengembalian yang diperoleh akan semakin tinggi dan berdampak pada besarnya kemakmuran pemilik (Ramadhani 2016). Tujuan utama perusahaan didirikan yaitu untuk memaksimumkan nilai perusahaan. Nilai perusahaan merupakan hal penting bagi investor terhadap perusahaan yang sering di kaitkan dengan harga saham yang dapat 
mensejahterakan para pemegang saham (Lisyanti dan Ukhriyawati 2017). Ada banyak hal yang dapat dilakukan perusahaan untuk meningkatkan nilai perusahaan salah satunya mengikuti program kinerja lingkungan karna kinerja lingkungan merupakan pertanggungjawaban perusahaan terhadap lingkungan. Di Indonesia perusahaan yang tingkat risiko lingkungannya tinggi sebagian besar adalah perusahaan yang bergerak dibidang pengusahaan hutan dan pertambangan umum. Kedua perusahaan tersebut adalah perusahaan yang berhubungan langsung dengan lingkungan, dimana bahan baku untuk diproses produksi diambil langsung dari alam. Seperti PT Lapindo Brantas di Sidoarjo dalam peristiwa menyemburnya lumpur panas dilokasi pengeboran dan PT Lapindo Brantas di Sidoarjo melakukan pembuangan lumpur yang diakibatkan dari pengeboran ke laut sehingga tidak sesuai dengan pengelolaan limbah B3 karena lumpur tersebut mengandung bahan berbahaya dan dapat mencemari ekosistem laut. Hal ini akan membuat fluktuasi harga saham akibat respon investor terhadap perusahaan dalam tanggungjawab perusahaan akibat dampak dari aktivitas perusahaan. Diera globalisasi saat ini ilmu pengetahuan dan teknologi mengalami perkembangan yang sangat pesat sehingga mempengaruhi perekonomian. Maka prinsip proses bisnis pun perlu diubah agar perusahaan dapat terus eksistensi dalam menjalankan bisnisnya. Kemampuan bersaing perusahaan tidak hanya terletak pada kepemilikan aktiva tidak berwujud, tetapi lebih pada inovasi, sistem informasi, pengelolaan organisasi dan sumber daya yang dimilikinya. Dapat dilihat kemajuan ternologi yang dimiliki perusahaan dapat mempengaruhi harga saham perusahaan. Seperti Harga saham perusahaan jasa transportasi PT Blue Bird Tbk (BIRD) mengalami kenaikan 4,32 \% menjadi Rp
2.900 per saham. Analis PT Asjaya Indosurya Securities, William Surya Wijaya mengatakan, kepercayaan investor akan saham BIRD kembali menguat berkat kerja sama BIRD dengsn Go-jek yang merupakan perusahaan transportasi berbasis online. (Kompam.com 2017) Oleh karena itu perusahaan semakin menitikberatkan akan pentingnya knowledge assets (aset pengetahuan). Dan dalam mengukur nilai perusahaan, beban pajak juga menjadi salah satu faktor yang mempengaruhi nilai perusahaan karena berakibat pada besarnya laba bersih yang diterima oleh suatu perusahaan. Dengan demikian perusahaan melakukan praktik penghindaran pajak yang digunakan untuk meminimalkan beban pajak yang ditanggung dengan memanfaatkan celah hukum di suatu negara sehingga transaksi tersebut legal karena tidak melanggar hukum yang berlaku. di Indonesia terdapat banyak perusahaan yang melakukan praktik penghindaran pajak. Asian Agri, Bumi Resources, Adaro, Indosat, Indofood, Kaltim Prima Coal (KPC) dan PT Airfast Indonesia ((Rusydi, 2014 dalam Prasiwi, 2015). Rumusan masalah penelitian adalajh apakah Environmental Performance berpengaruh terhadap Nilai Perusahaan? Apakah Intellectual Capital berpengaruh terhadap Nilai Perusahaan? Apakah Praktik Penghindaran Pajak berpengaruh terhadap Nilai Perusahaan? Apakah Environmental Performance, Intellectual Capital dan Praktik Penghindaran Pajak berpengaruh terhadap Nilai Perusahaan?

\section{Agency Theory}

Penelitian ini menggunakan teori agensi karena teori ini menjelaskan hubungan kontraktual antara principal dan agents. Pihak principals adalah pihak yang memberikan mandat kepada pihak lain yaitu agent, untuk melakukan semua kegiatan atas nama 
principals dalam kapasitasnya sebagai pengambil keputusan (Syahfitri 2016). Pemisahan kepemilikan antara pemilik perusahaan dengan manajemen sering menimbulkan konflik. Konflik ini akan timbul ketika perbedaan antara tujuan pemegang saham dengan manajemen yaitu pemegang saham ingin meningkatkan nilai perusahaan dengan adanya praktik penghindaran pajak agar perusahaan dapat mempertahankan laba maksimal sehingga investor percaya bahwa investasi yang dilakukan akan mendapatkan pengembalian yang besar seperti mendapatkan dividen sedangkan manajemen mementingkan kepentingan pribadi seperti manajer akan melakukan praktik penghindaran pajak apabila perusahaan dapat memberikan manfaat kepada manajer (Syahfitri 2016).

\section{Stakeholder Theory}

Menurut Belkaoui (2003) dalam Zuliyati (2011) Teori stakeholder lebih mempertimbangkan posisi para stakeholder yang dianggap powerfull. Kelompok stakeholder inilah yang menjadi pertimbangan utama bagi perusahaan dalam mengungkapkan dan/atau tidak mengungkapkan suatu informasi di dalam laporan keuangan. (Satiti dan Asyik, 2013) Stakeholder theory menyatakan bahwa organisasi akan memilih secara sukarela mengungkap informasi tentang kinerja lingkungan, sosial, dan intelektual yang mereka miliki melebihi di atas permintaan wajibnya untuk memenuhi ekspektasi sesungguhnya atau yang diakui oleh stakeholder.

\section{Nilai perusahaan}

Menurut

Syahfitri

mengungkapkan bahwa nilai perusahaan merupakan harga yang bersedia dibayar oleh calon investor jika suatu perusahaan akan dijual. Nilai perusahaan sangat penting karena mencerminkan kinerja perusahaan yang dapat mempengaruhi persepsi investor terhadap perusahan (Syahfitri 2016). Menurut (Keown, 2004 dalam Juwita dan Angela, 2016) nilai perusahaan merupakan nilai pasar atas surat berharga hutang dan ekuitas perusahaan yang beredar. Tujuan jangka panjang perusahaan adalah memaksimumkan nilai perusahaan. Sehingga apabila suatu perusahaan dianggap memiliki nilai maka perusahaan itu berharga atau dalam artian memiliki prospek masa depan. Optimalisasi nilai perusahaan yang merupakan tujuan perusahaan dapat dicapai melalui pelaksanaan fungsi manajemen keuangan, dimana suatu keputusan keuangan yang diambil akan mempengaruhi keputusan keuangan lainnya dan berdampak pada nilai perusahaan (Sudibya dan Restuti 2014).

\section{Environmental Performance}

Menurut Fitriani (2013), Kinerja lingkungan adalah kinerja perusahaan dalam menciptakan lingkungan yang baik atau green. Dengan demikian, kinerja lingkungan merupakan kinerja perusahaan yang berfokus pada kegiatan perusahaan dalam melestarikan lingkungan dan mengurangi dampak lingkungan yang timbul akibat aktivitas perusahaan. Salah satu informasi yang sering diungkapkan oleh perusahaan adalah informasi mengenai kebijakan perusahaan terhadap lingkungan, karena hal ini dianggap sebagai inti dari etika bisnis perusahaan. Perusahaan tidak hanya mempunyai kewajiban finansial seperti kepada para pemegang saham atau shareholder tetapi juga kewajiban terhadap pihak lain yang jangkauannya lebih luas yaitu: konsumen, karyawan, lingkungan dan komunitas dalam segala aspek operasional perusahaan. Kinerja lingkungan diukur dari prestasi perusahaan yang mengikuti Program Penilaian Peringkat Kinerja Perusahaan dalam Pengelolaan Lingkungan 
Hidup (PROPER). Program ini merupakan salah satu upaya yang dilakukan oleh Kementerian Lingkungan Hidup (KLH) untuk mendorong pentaatan perusahaan dalam mengelola lingkungan hidup. PROPER diumumkan secara rutin kepada masyarakat, sehingga perusahaan yang dinilai akan mendapat insentif maupun disinsentif reputasi, tergantung pada tingkat ketaatannya (Setyaningsih 2016).

\section{Intellectual Capital}

Menurut

Juwariyah

mendefinisikan intellectual capital sebagai suatu pengetahuan perusahaan yang dapat digunakan dalam proses bisnis untuk menciptakan value added bagi perusahaan. Investor akan memberikan nilai yang lebih tinggi pada perusahaan yang memiliki sumber daya intelektual yang lebih tinggi dibandingkan dengan perusahaan yang memiliki sumber daya intelektual yang rendah.

\section{Intellectual Capital}

Menurut Tarigan, (2011) Human capital juga merupakan tempat bersumbernya pengetahuan yang sangat berguna, keterampilan, dan kompetensi dalam suatu organisasi atau perusahaan.

Menurut Wahdikorin, (2010) Structural Capital (SC) adalah infrastruktur yang dimiliki oleh suatu perusahaan dalam memenuhi aktivitas bisnisnya. Structural capital meliputi sistem teknologi, sistem operasional perusahaan, hak paten, merk dagang dan kursus pelatihan.

Customer capital merupakan hubungan perusahaan dengan pihak di luar perusahaan seperti pemerintah, pasar, pemasok dan pelanggan, bagaimana loyalitas pelanggan terhadap perusahaan. Customer capital juga dapat diartikan kemampuan perusahaan untuk mengidentifikasi kebutuhan dan keinginan pasar sehingga menghasilkan hubungan baik dengan pihak luar.

\section{Praktik Penghindaran Pajak}

Menurut Suandy (2011:7) Penghidaran pajak adalah rekayasa tax affairs yang masih tetap berada dalam bingkai ketentuan perrpajakan (lawful). Penghindaran pajak dapat terjadi didalam bunyi ketentuan atau tertulis di undang-undang dan berada dalam jiwa dari undang undang atau dapat juga terjadi dalam bunyi ketentuan undang-undang tetapi berlawanan dengan jiwa undang-undang. Dalam melakukan praktik penghindaran pajak maka menurut Suandy (2011:9) menjelaskan setidaktidaknya terdapat tiga hal yang harus diperhatikan dalam suatu perencanaan pajak, yaitu:

1. Tidak melanggar ketentuan perpajakan.

Bila suatu perencanaan pajak dipaksakan dengan melanggar ketentuan perpajakan, bagi wajib pajak merupakan risiko pajak yang sangat berbahaya dan justru mengancam keberhasilan perencanaan pajak tersebut.

\section{Secara bisnis masuk akal,}

karena perencanaan pajak merupakan bagian yang tidak terpisah dari perencanaan menyeluruh (global strategy) perusahaan, baik jangka panjang maupun jangka pendek. Oleh karena itu, perencanaan pajak yang tidak masuk akal akan memperlemah perencanaan itu sendiri.

3. Bukti-bukti pendukungnya memadai, misalnya dukungan perjanjian (agreement), faktur (invoice) dan juga perlakuan akuntansinya (accounting treatment).

\section{Hasil Penelitian Terdahulu}

$$
\text { Menurut Anggraeni }
$$

Pengungkapan emisi rumah kaca, kinerja lingkungan secara parsial memiliki pengaruh 
yang signifikan dan positif terhadap nilai perusahaan. Sedangkan Sudibya dan Restuti 2014 menyatakan bahwa modal intelektual berpengaruh positif terhadap kinerja keuangan perusahaan dan modal intelektual terbukti lebih baik berpengaruh secara langsung terhadap nilai pasar perusahaan daripada dimediasi oleh kinerja keuangan. Dan penelitian yang dilakukan Syafitri, 2016 menyatakan Tax avoidance yang diproksikan melalui GAAP ETR berpengaruh negatif dan signifikan terhadap nilai perusahaan.

\section{Pengaruh Environmental Performance terhadap Nilai Perusahaan}

Dalam penelitian Hariati dan Rihatiningtyas (2014) menemukan adanya hubungan positif kinerja lingkungan terhadap nilai perusahaan. Sebab apabila perusahaan mampu memperhatikan pengelolaan lingkungannya, maka keberadaan perusahaan tersebut akan direspon positif oleh masyarakat. Investor lebih berminat pada perusahaan yang memiliki citra/image baik di masyarakat karena berdampak pada tingginya loyalitas konsumen yang pada akhirnya juga berdampak pada peningkatan nilai perusahaan.

H1: Diduga Environmental Performance berpengaruh terhadap Nilai Perusahaan.

\section{Pengaruh Intellectual Capital terhadap Nilai Perusahaan}

Penelitian yang dilakukan oleh Indrajaya, (2015) bahwa modal intelektual berpengaruh terhadap nilai perusahaan yang diukur dengan Price to Book Value (PBV) dan Earning Per Share (EPS) hasil temuan penelitian ini mengindikasikan bahwa semakin efisien perusahaan mengelola sumber daya intelektual (physical capital, human capital dan structural capital) yang dimiliki perusahaan akan memberikan hasil yang meningkat yang ditunjukkan.
H2: Diduga Intellectual Capital berpengaruh terhadap Nilai Perusahaan.

\section{Pengaruh Praktik Penghindaran Pajak terhadap Nilai Perusahaan}

Penelitian yang dilakukan Syahfitri (2016) Tax avoidance yang diproksikan melalui GAAP ETR berpengaruh negatif dan signifikan terhadap nilai perusahaan. Maka dapat disimpulkan bahwa hasil penelitian ini memiliki arti semakin tinggi nilai GAAP ETR maka semakin rendah penghindaran pajak di suatu perusahaan. Semakin rendah penghindaran pajak maka pengaruhnya nilai perusahaan semakin rendah.

H3: Diduga Tax Avoidance berpengaruh terhadap Nilai Perusahaan

\section{METODA PENELITIAN}

Penelitian dilakukan pada perusahaan yang terdaftar di Bursa Efek Indonesia (BEI) dan Kementrian Lingkungan Hidup (KLH) pada periode 5 tahun mulai tahun 2012-2016. Pemilihan lokasi penelitian di Bursa Efek Indonesia (BEI) melalui situs resminya www.idx.co.id dan situs resmi Kementrian Lingkungan Hidup www.menlh.go.id didasarkan atas pertimbangan objektif sesuai dengan tujuan penelitian serta pertimbangan.

Nilai perusahaan ini digunakan sebagai pengukur keberhasilan. Dalam penelitian ini Nilai perusahaan dinilai berdasarkan rasio Tobin's $q$. Tobin's $q$ adalah indikator untuk mengukur kinerja perusahaan, khususnya tentang nilai perusahaan, yang menunjukkan suatu performa manajemen dalam mengelola aktiva perusahaan.

$\mathrm{Q}=\frac{(M V S+D)}{T A}$

Keterangan:

MVS: Nilai pasar saham (market value of all outstanding shares) yang diperoleh dari hasil 
perkalian jumlah saham yang beredar dengan harga saham penutup (outstanding share $x$ closing share)

D : Nilai buku total hutang

TA : Nilai buku total aktiva perusahaan

Menurut Suratno et al. (2006) dalam Tjahjono (2013) kinerja lingkungan perusahaan (Environmental Performance) adalah kinerja perusahaan dalam menciptakan lingkungan yang baik (green). Di Indonesia, penerapan kinerja lingkungan perusahaan difasilitasi dengan adanya Program Penilaian Peringkat Kinerja Perusahaan dalam Pengelolaan Lingkungan Hidup (PROPER), yaitu instrumen yang digunakan oleh Kementrian Lingkungan Hidup (KLH) untuk melakukan penilaian dan pemeringkatan ketaatan perusahaan dalam melakukan kinerja lingkungannya (Fitriani, 2013). Program PROPER diukur berdasarkan warna yang menjadi tolok ukur prestasi tiap perusahaan sampel. PROPER meliputi lima (5) warna yakni:

Tabel 1 Penilaian Skor PROPER

\begin{tabular}{|c|c|c|}
\hline Warna & Skor & Nilai \\
\hline Emas & 5 & $\begin{array}{l}\text { Sangat-sangat } \\
\text { baik }\end{array}$ \\
\hline Hijau & 4 & Sangat baik \\
\hline Biru & 3 & Baik \\
\hline Merah & 2 & Buruk \\
\hline Hitam & 1 & Sangat buruk \\
\hline
\end{tabular}

Menurut Sawarjuwono dan Kadir (2003) dalam Sudibya dan Restuti (2014) mendefinisikan modal intelektual sebagai jumlah dari apa yang dihasilkan oleh tiga elemen utama organisasi (Human Capital, Structural Capital, Customer Capital) yang berkaitan dengan pengetahuan dan teknologi yang dapat memberikan nilai lebih bagi perusahaan berupa keunggulan bersaing organisasi. Pengukuran kinerja modal intelektual berdasarkan model yang dikembangkan oleh
(Pulic 1998, 1999, 2000, 2003 dalam Widarjo, 2011). Formulasi perhitungan $V A I C^{T M}$ adalah sebagai berikut:

(a) Menghitung Value Added (VA). Nilai tambah atau Value Added (VA) adalah perbedaan antara penjualan (OUT) dan input (IN). Rumus untuk menghitung VA yaitu :

VA = OUT - IN

Keterangan:

Output $($ OUT $)=$ Total penjualan dan pendapatan lain.

Input $(\mathrm{IN})$ = Beban dan biaya-biaya (selain beban karyawan).

Value Added (VA)= Selisih antara output dan input.

(b) Menghitung Value Added Capital Employed (VACA)

VACA merupakan indikator efisiensi nilai tambah (Value Added/VA) modal yang digunakan. Rumus untuk menghitung VACA yaitu Keterangan: $\mathrm{VACA}=\mathrm{VA} / \mathrm{CE}$

Value Added (VA) = Value Added

Capital Employed (CE) = Dana yang tersedia (ekuitas, laba bersih)

(c) Menghitung Value Added Human Capital (VAHU)

Rumus untuk menghitung VAHU yaitu Keterangan:

$\mathrm{VAHU}=\mathrm{VA} / \mathrm{HC}$

Value Added $(\mathrm{VA})=$ Value Added

Human Capital $(\mathrm{HC})=$ Beban karyawan

(d) Menghitung Structural Capital Value Added (STVA)

Keterangan:

VASC $=$ SC $/$ A

Structural Capital (SC): Selisih antara Value Added (VA) dengan Human Capital (HC)

Human Capital (HC): Beban karyawan 
(e) Value Added Intellectual Coefficient $\left(V_{A I C^{T M}}\right)$

$$
V A I C^{T M}=\mathrm{VACE}+\mathrm{VAHC}+\mathrm{VASC}
$$

Menurut Herdiyanto

Penghindaran Pajak (tax avoidance) merupakan usaha yang dilakukan oleh perusahaan untuk mengurangi beban pajaknya. Penghindaran Pajak dilakukan dengan memanfaatkan celahcelah yang ada dalam peraturan perundangundangan selain memberikan keuntungan bagi pihak perusahaan, penghindaran pajak juga dapat memberikan efek negatif bagi perusahaan. Penelitian ini mengukur Praktik Penghindaran Pajak dengan menggunakan CASH ETR menurut Herdiyanto, (2015) dengan formulasi rumus sebagai berikut:

Cash_ETR $=\frac{\text { Cash } \text { Tax } \text { Paid }}{\text { Pretax } \text { Income }}$

Keterangan:

Cash_ETR = Effective Tax Rates sebagai indikator tax avoidance

Cash Tax Paid = Beban pajak yang dibayar oleh perusahaan (Didapat dari laporan arus kas konsolidasian)

Pretax Income = Laba perusahaan sebelum pajak (Laporan Laba Rugi

Komprehensif Konsolidasian)

Metode pengambilan sampel yang digunakan dalam penelitian ini adalah purposive sampling. Purposive sampling adalah cara pengambilan sampel dengan menetapkan ciri sesuai kriteria. Kriteria perusahaan yang dijadikan sampel penelitian adalah:

1 Perusahaan manufaktur yang terdaftar di Bursa Efek Indonesia (BEI) selama periode penelitian (2012-2016).
2 Perusahaan tidak delesting atau keluar dari BEI selama periode penelitian (2012-2016).

3 Perusahaan yang mendapat peringkat PROPER dari Kementerian Lingkungan Hidup berturut turut selama periode 20122016

4 Perusahaan yang menyajikan laporan keuangan dalam satuan rupiah secara berturut-turut dalam periode 2012-2016

5 Laporan keuangan tersebut terdapat informasi yang lengkap terkait dengan semua variabel yang diteliti.

Dalam penelitian ini menggunakan metode Regresi Linear Berganda yang digunakan untuk mengukur pengaruh antara lebih dari satu variabel independen (variabel bebas) terhadap variabel dependen, metode ini diyakini mempunyai sifat-sifat yang ideal dan dapat diunggulkan, yaitu secara teknis sangat kuat, mudah dalam perhitungan dan penarikan interprestasinya. Persamaan regresi linear berganda sebagai berikut:

$y=a+b_{1} X_{1}+b_{2} X_{2}+b_{3} X_{3}+e$

Keterangan:

$\mathrm{Y}=$ Nilai Perusahaan

a = Konstanta

$X_{1}=$ Environmental Performance

$X_{2} \quad=$ Intellectual Capital

$X_{3}=$ Praktik Penghindaran Pajak

$b_{1}, b_{2}, b_{3}=$ Koefisien regresi

$\mathrm{e}=$ Standar eror

\section{HASIL PENELITIAN}


Tabel 2 Hasil Pengujian Hipotesis

\begin{tabular}{lrrrr}
\hline Variabel & \multicolumn{1}{c}{ B } & \multicolumn{1}{c}{ Std. Error } & \multicolumn{1}{c}{ T } & \multicolumn{1}{c}{ Sig. } \\
\hline Konstanta & 318.355 & 133.648 & 2.382 & .023 \\
PROPER & -19.984 & 43.919 & -.455 & .652 \\
VAICTM & .234 & .073 & 3.203 & .003 \\
CETR & -4.311 & 1.981 & -2.176 & .036 \\
\hline
\end{tabular}

Berdasarkan hasil pengujian bahwa hipotesis tsb menunjukkan $\mathrm{H} 1$ ditolak. Hal ini menunjukkan bahwa secara parsial Environmental Performance tidak berpengaruh secara signifikan terhadap nilai perusahaan. Hal ini dapat dilihat dari nilai signifikan tabel lebih besar dari nilai signifikansi yang ditentukan $(0,652$ $>0,05$ ) Penelitian ini menunjukkan bahwa perusahaan yang mendapat peringkat PROPER belum tentu memberikan keuntungan kepada investor. Meskipun pemerintah telah menetapkan peraturan tentang pengelolaan lingkungan hidup, akan tetapi hasil pelaksanaan kegiatan PROPER masih jauh dari harapan karena masih banyak perusahaan di Indonesia yang tergabung dalam PROPER masih mendapatkan peringkat hitam. Hal tersebut menggambarkan masih banyak perusahaan yang memberi andil dalam masalah pencemaran lingkungan di Indonesia baik pencemaran lingkungan maupun pencemaran udara.

Berdasarkan hasil pengujian bahwa hipotesis tsb menunjukkan $\mathrm{H} 2$ diterima. Hal ini menunjukkan bahwa secara parsial Intellectual Capital berpengaruh signifikan terhadap Nilai Perusahaan. Hal ini dapat dilihat dari nilai signifikan tabel lebih kecil dari nilai signifikansi yang ditentukan $(0,003<0,05)$. Hasil penelitian ini sesuai dengan teori stakeholder yang menyatakan bahwa pengelolaan seluruh sumber daya perusahaan berupa Physical Capital, Human Capital dan Structural Capital akan mendorong pembentukan nilai tambah bagi perusahaan, nilai tambah berupa Intellectual Capital dapat menarik perhatian investor untuk berinvestasi sehingga nilai perusahaan akan meningkat. Dan perusahaan yang memiliki Intellectual Capital akan memberikan keuntungan bagi perusahaan tempat mereka berinvestasi karna hal tersebut direspon positif oleh pelaku pasar melalui meningkatnya harga saham.

Berdasarkan hasil pengujian bahwa hipotesis tsb menunjukkan $\mathrm{H} 3$ diterima. Hal ini menunjukkan bahwa secara parsial Praktik Penghindaran Pajak berpengaruh signifikan terhadap Nilai Perusahaan. Hal ini dapat dilihat dari nilai signifikan tabel lebih kecil dari nilai signifikansi yang ditentukan $(0,036>0,05)$. Hasil penelitian ini berarti bahwa semakin tinggi praktik penghindaran pajak maka semakin rendah nilai perusahaan, Karena ada beberapa biaya yang harus ditanggung yaitu pengorbanan waktu dan tenaga untuk melakukan penghindaran pajak serta adanya risiko jika penghindaran pajak terungkap

\section{PENUTUP}

Berdasarkan hasil dari analisis data dan pembahasan maka kesimpulan yang dapat diambil dari penelitian adalah Environmental Performance tidak berpengaruh terhadap Nilai Perusahaan. Penelitian ini menunjukkan bahwa perusahaan yang mendapat peringkat PROPER belum tentu memberikan keuntungan kepada investor karena hasil pelaksanaan kegiatan PROPER masih jauh dari harapan oleh karena itu masih banyak perusahaan di Indonesia yang 
tergabung dalam PROPER yang masih mendapatkan peringkat hitam.

Intellectual Capital berpengaruh

terhadap Nilai Perusahaan. Hasil ini sesuai dengan teori stakeholder yang menyatakan bahwa pengelolaan seluruh sumber daya perusahaan berupa physical capital, human capital dan structural capital akan mendorong pembentukan nilai tambah bagi perusahaan, nilai tambah berupa intellectual capital dapat menarik perhatian investor untuk berinvestasi sehingga nilai perusahaan akan meningkat.

Praktik penghindaran Pajak

berpengaruh terhadap Nilai Perusahaan. Hal ini berarti bahwa semakin tinggi praktik penghindaran pajak maka semakin rendah nilai perusahaan. Karena ada beberapa biaya yang harus ditanggung yaitu pengorbanan waktu dan tenaga untuk melakukan penghindaran pajak serta adanya risiko jika penghindaran pajak terungkap. Risiko ini dimulai dari yang terlihat yaitu bunga dan denda sedangkan resiko yang tidak terlihat yaitu kehilangan reputasi perusahaan yang berakibat buruk bagi kelangsungan usaha jangka panjang perusahaan.

\section{REFERENSI:}

Anggraeni, D. Y. 2015. Pengungkapan emisi rumah kaca, kinerja lingkungan tehadap Nilai Perusahaan. Jurnal Akuntansi dan keuangan Indonesia. Sekolah Tinggi Ekonomi Islam (STEI) Tazkia. 12(2) Desember.

Fitriani, A. 2013. Pengaruh Kinerja Lingkungan Dan Biaya Lingkungan Terhadap Kinerja Keuangan Pada Bumn. Jurnal IImu Manajemen. Universitas Negeri Surabaya. 1(1) Januari.

Hariati, I., dan Yeney W. R. 2014. Pengaruh Tata Kelola Perusahaan dan Kinerja Lingkungan Terhadap Nilai Perusahaan. Malang: Universitas Brawijaya.

Herdiyanto, D. G. 2015. Pengaruh Tax Avoidance terhadap Nilai Perusahaan. Semarang: Fakultas Ekonomika dan Bisnis Universitas Ponegoro.

Indrajaya, A. 2015. Pengaruh Modal Intelektual Terhadap Nilai Perusahaan. Yogyakarta: Fakultas Ekonomi Universitas Sanata Dharma.

Julioe, R. 2017. Pengaruh Book-Tax Differences terhadap Pertumbuhan Laba (Studi Empiris Pada Perusahaaan Yang Terdaftar Dalam Jakarta Islamic Index (Jii) Tahun 2012-2014. Fakultas Ekonomi Dan Bisnis Islam Institut Agama Islam Negeri Surakarta.

Juwariyah, E. S. 2014. Pengaruh Intellectual Capital terhadap Nilai Perusahaan Melalui Kinerja Keuangan Sebagai Variabel Intervening. Surabaya: Fakultas Ekonomika dan Bisnis Universitas Airlangga.

Juwita, R dan Aurora, A. 2016. Pengaruh Intellectual Capital Terhadap Nilai Perusahaan pada Perusahaan Indeks Kompas 100 di Bursa Efek Indonesia. Bandung: Jurnal Akuntansi, 8(1) Mei.

Lisyanti, S. E dan Catur, F. U. 2017. Pengaruh Kinerja Keuangan, Corporate Social Responsibility Dan Good Corporate Governance Terhadap Nilai Perusahaan. Jurnal Manajemen, 4(2).

Prasiwi, K. W. 2015. Pengaruh Penghindaran Pajak Terhadap Nilai Perusahaan: Transparansi Informasi Sebagai Variabel Pemoderasi. Semarang: Fakultas Ekonomi Universitas Diponegoro.

Ramadhani, N. D. 2016. Pengaruh Kebijakan Utang, Tax Avoidance dan Size Terhadap Nilai Perusahaan. Tangerang Selatan: Fakultas Ekonomi Universitas Pamulang.

Satiti, A dan Asyik, N. F. 2013. Pengaruh Intellectual Capital Terhadap Kinerja Keuangan Perusahaan Asuransi. Surabaya: Jurnal IImu \& Riset Akuntansi, 2(7).

Setyaningsih, R. D. 2016. Pengaruh Kinerja Lingkungan Terhadap Kinerja Keuangan Dengan Corporate Social Responsibility Sebagai Pemoderasi. Surabaya: Jurnal Ilmu dan Riset Akuntansi, 5(4), April. 
Sudibya, D. C. N. A dan MI Mitha D. R. 2014. Pengaruh Modal Intelektual Terhadap Nilai Perusahaan Dengan Kinerja Keuangan Sebagai Variabel Intervening. Salatiga: Jurnal manajemen dan bisnis, 18(1) Juni. 14 29.

Syahfitri, P. 2016. Pengaruh Tax Avoidance Terhadap Nilai Perusahaan. Bandar Lampung: Fakultas ekonomi dan bisnis Universitas Lampung.

Tjahjono, M. E. S. 2013. Pengaruh Kinerja Lingkungan Terhadap Nilai Perusahaan Dan Kinerja Keuangan. Jurnal Ekonomi, 4(1) Mei.

Zuliyati. 2011. Intellectual Capital Dan Kinerja Keuangan Perusahaan. Dinamika Keuangan dan Perbankan, 3(1) November. 